\title{
PENGARUH KONSENTRASI BAYCLIN PADA PENCUCIAN II DAN BAP PADA MEDIA MS TERHADAP PERTUMBUHAN EKSPLAN TANAMAN PISANG KLUTUK (Musa paradisiaca. L) SECARA IN VITRO
}

\section{Effect of Bayclin Concentration on Washing II and BAP in MS Media on Eksplan Growth of Klutuk Banana (Musa paradisiaca. L) In-vitro}

\author{
Zulkifli dan Putri Lukmana Sari \\ Fakultas Pertanian Universitas Ialam Riau, \\ Jl. Kaharudin Nasution No. 133 Perhentian Marpoyan Pekanbaru 28284 Riau. \\ Telp: 0761-674681, Fax: 0761-67468. Email; Ir.Zulkifli-ms@ gmail.com \\ [Diterima Januari 2017; Disetujui Juli 2016]
}

\begin{abstract}
This research aims to examie the effect of bayclin concentration on washing II and BAP in MS media on eksplan growth of klutuk banana in vitro and was conducted at the Tissue Culture Laboratory Lempes Pekanbaru from April to August 2016. The research used a completely randomized design (CRD) with 3 factorials and 3 replications. The first factor was the concentration of washing eksplan bayclin on phase II which consisted of four levels: K0 (concentration of 0\%), K1 (concentration of 10\%), K2 (concentration of 20\%), and K3 (concentration of 30\%). The second factor was the concentration of BAP contained on media MS consisted of four levels: T0 (BAP concentration $0 \mathrm{mg} / \mathrm{liter}$ ), T1 (BAP concentration of $0.1 \mathrm{mg} / \mathrm{liter}$ ), T2 (BAP concentration of 1.0 $\mathrm{mg} / \mathrm{liter}$ ) and T3 (BAP concentration of $10.0 \mathrm{mg} / \mathrm{liter}$ ). The parameters observed were percentage of explants contaminated, age appears buds, the number of shoots/explant, length of shoots/explant, number of roots/explant (root), root length/explant and percentage of explant life. The results showed that effect of concentration on the washing bayclin II and BAP in MS Media on growth eksplan of klutuk banana in-vitro was the best treatment K2T2 with $33.33 \%$ of explants contaminated, age of appears buds 2,67 weeks after planting, the number of shoots 2,67/explant, length of shoots 5,50 $\mathrm{cm} /$ explant, number of roots 2.67/explant, root length 12,08 cm/explant and 58.33\% of explants life.
\end{abstract}

Keywords: Bayclin, awashing II, BAP, Media MS, Eksplan, Banana klutuk.

\section{ABSTRAK}

Penelitian bertujuna untuk mengetahui pengaruh interaksi kosentrasi bayclin pada pencucian Ke- II dan BAP terhadap pertumbuhan ekplan tanaman pisang klutuk dan mencari kosentrasi bayclin dan BAP yang tepat dalam perbanyakan bibit pisang klutuk secara in-vitro dan telah dilakukan di Laboratorium Kultur Jaringan (LEMPES) dari bulan April sampai Agustus 2016. Penelitian ini menggunakan rancangan acak lengkap (RAL) dengan 2 faktor dan 3 ulagan. Faktor pertama adalah konsentrasi pencucian Eksplan Bayclin pada fase II yang terdiri dari 4 (empat) tingkatan: K0 (konsentrasi 0\%), K1 (konsentrasi 10\%), K2 (konsentrasi 20\%), K3 (konsentrasi 30\%). Faktor kedua adalah konsentrasi BAP yang terkandung pada media MS terdiri dari empat (4) tingkatan: T0 (konsentrasi BAP 0 mg/liter), T1 (BAP konsentrasi 0,1 mg/liter), T2 (BAP konsentrasi 1,0 mg/liter), dan T3 (BAP konsentrasi 10,0 mg/liter). Parameter yang diamati adalah persentase eksplan yang terkontaminasi, umur munculnya tunas, jumlah tunas/eksplan, panjang tunas/eksplan, jumlah akar/eksplan, panjang akar/eksplan dan persentase eksplan hidup. Hasil penelitian menunjukkan bahwa pengaruh konsentrasi pada pencucian ke II bayclin dan konsentrasi BAP pada Media MS terhadap pertumbuhan eksplan pisang klutuk secara in vitro menghasilkan perlakuan terbaik K2T2 dengn kontaminasi eksplan 33,33\%, umur munculnya tunas 2,67 minggu setelah tanam, jumlah tunas 2,67/eksplan, panjang tunas 5,50 cm/eksplan, jumlah akar 2,67/eksplan, panjang akar 12,08 $\mathrm{cm} /$ eksplan dan persentase eksplan yang hidup 58,33\%.

Katakunci: Bayclin, Pencucian II, BAP, Media MS, Ekspaln da Pisang Klutuk 


\section{PENDAHULUAN}

Pisang adalah tanaman yang memiliki fungsi ganda, gizi yang terkandung sebagai sumber vitamin, mineral dan juga karbohidrat. Daunnya dapat digunkana sebagai pembungkus berbagai macam/jenis makanan trandisional Indonesia yang memiliki keistimewaan yang dapat menghasilkan aroma lebih enak. Fungsi lain secara tradisional air umbi batang pisang dimanfaatkan sebagai obat disentri dan pendarahan usus besar, sedangkan air batang pisang digunakan sebagai obat sakit kencing dan penawar racun (Abdurrahman, 2011). Untuk itu pisang sangat cocok dikembangkan.

Pembibitan memiliki peranan penting dalam pengembangan pisang. Saat ini bibit yang ditanam petani umumnya dari anakan pohon induk, sehingga jumlah anakan yang dihasilkan terbatas dan sulit mendapatkan bibit yang bebas serangan penyakit layu Fusariumun maupu bakteri. Teknik kultur jaringan merupakan alternatif untuk menghasilkan bibit pisang yang bermutu dalam jumlah banyak, seragam, dan dapat dihasilkan dalam waktu singkat. Kultur jaringan merupakan suatu teknik untuk mengisolasi bagian dari tanaman seperti titik tumbuh, organ, sekelompok sel atau bahkan sel, serta menumbuhkannya dalam lingkungan aseptic, sehingga bagian tersebut dapat memperbanyak diri menjadi tanaman baru yang lengkap persis sama dengan induknya (Asnin, 2010).

Dalam perbanyakan tanaman secara kultur jaringan perlu diperhatikan media kultur dan bahan pembersih yang digunakan. Bayclin adalah bahan yang mengandung Natrium hipoklorit yang digunakan untuk mencegah terjadinya infeksi atau pencemaran oleh jasad renik untuk membasmi kuman penyakit. Bayclin adalah senyawa kimia yang bersifat toksik dan memiliki kemampuan membunuh mikroorganisme yang terpapar secara langsung. Oleh sebab itu bayclin ini dipakai sebagai bahan desinfektan pada eksplan yang akan dikembangkan secara kultur jaringan (Sandra, 2010).

Oleh karena itu, semua organisme baru yang berhasil ditumbuhkan akan memiliki sifat yang sama persis dengan induknya. Untuk berhasilnya pekerjaan kultur jaringan tidak terlepas dari penggunaan ZPT pada media yang akan kita pakai dalam pengkulturan.

Secara umum, zat pengatur tumbuh yang digunakan dalam kultur in-vitro ada tiga kelompok besar, yaitu auksin, sitokinin dan giberelin. Auksin berfungsi untuk merangsang pertumbuhan akar, sitokinin untuk pertumbuhan tunas pucuk, dan giberelin untuk diferensiasi atau perbanyakan fungsi sel. Sitokinin (BAP), merupakan kelompok hormon tumbuhan yang sangat penting sebagai pemacu pertumbuhan dan morfogenesis yang digunakan dalam kultur jaringan.

Oleh sebab itu telah dilakukan penelitian denna tujuan untuk mengetahui pengaruh interaksi kosentrasi Bayclin pada pencucian KeII dan BAP terhadap Pertumbuhan Ekplan tanaman pisang klutuk dan untuk mencari kosentrasi bayclin dan BAP yang tepat dalam perbanyakan bibit pisang klutuk secara in-vitro.

\section{METODE PENELITIAN}

Penelitian ini dilakukan selama 5 bulan dari bulan April sampai Agustus 2016. Adapun tempat penelitian di Labor Kultur Jaringan LEMPES, Jl. Penerbangan, Gg. Rahmat No. 87 Kelurahan Simpang Tiga, Kecamatan Bukit Raya, Kota Pekanbaru.

Bahan yang digunakan dalam penelitian ini Anakan Pisang Klutuk (ukuran Tinggi 50 $\mathrm{cm}$,memiliki 5 helai daun) berasal dari Kebun Masyarakat (Teratak Buluk, Kabupaten Kampar, Riau), Bayclin, BAP, Aquades, Larutan Stok, sunlight,Asam Ascorbat, agaragar, gula, spritus, kertas lakmus, aluminium voil, karet dan palastik. alat yang digunakan berupa; parang, tembilang, meteran, timbangan analitik, laminar air flow cabinet, autoklaf, oven listrik, alat penggaris, glass ukur, erlenmeyer, patridis, botol, pisau scapel, pinset, handsprayer, rakkultur, shaker, toples plastik, spatulla dan seperangkat alat tulis lainnya.

Penelitian ini menggunakan Rancangan Acak Lengkap (RAL), Faktorial dengan 2 faktor perlakuan sebagai berikut: Faktor pertama adalah Konsentrasi Bayclin pada pencucian Eksplan tahap II yang terdiri dari 4 ( empat ) level :K0. Kosentrasi 0 persen selama 30 menit. K1. Kosentrasi 10 persen selama 30 menit . K2. Kosentrasi 20 persen selama 30 menit. K3. Kosentrasi 30 persen selama 30 menit. Faktor kedua adalah Kosentrasi BAP yang terdapat pada midia MS terdiri dari 4 (empat) level : T0. Kosentrasi BAP $0 \mathrm{mg}$ per liter larutan. T1. Kosentrasi BAP 0,1 mg per liter larutan. T2. Kosentrasi BAP $1.0 \mathrm{mg}$ per liter larutan. T3. Kosentrasi BAP $10.0 \mathrm{mg}$ per liter larutan. 
Dengan demikian terdapat 16 kombinasi perlakuan yang masing-masingnya 3 ulangan dan setiap unit percobaan terdiri dari 1 botol, setiap botol ditanam 1 eksplan dan langsung dijadikan sampel sehingga berjumlah 48 unit percobaan. Prosedur Penelitian terdiri atas Persiapan Media, Persiapan Eksplan, Perlakuan perlakuan Bayclin dan BAP, Penanaman, Pemeliharaan dan Pengamatan meliputi Persentase Eksplan Terkontaminasi (\%), Panjang Tunas/ Eksplan $(\mathrm{cm})$, Panjang akar/eksplan $(\mathrm{cm})$ dan Persentase Eksplan Hidup (\%).

\section{HASIL DAN PEMBAHASAN}

\section{Persentase Eksplan Terkontaminasi (\%)}

Hasil pengamatan menunjukkan bahwa pengaruh konsentrasi bayclin dan BAP pada Media MS Terhadap Persentase Eksplan Terkontaminasi secara interaksi berbeda nyata sebagaimana ditampilkan pada Tabel 1 .

Dari Tabel 1 terlihat bahwa Rerata Persentase Eksplan Terkontaminasi secara interaksi pengaruh nyata, dimana angka terendah terdapat pada perlakuan $\mathrm{K}_{2} \mathrm{~T}_{0} 25 \%$, bebeda nyata dengan perlakuan K3T0, K3T1, K3T2, K0T3, K1T3, K3T3 dan tidak berbeda nyata dengan K0T0, K1T0, K0T1, K1T1, K2T1, K0T2, K1T2, K2T2,K2T3 dan yang tertinggi pada perlakuan K3T3 tidak berbeda nyata dengan perlakuan K2T1, K3T1, K0T2, K3T2, K0T3, K1T3. Sehingga dari hasil kajian ini terjadinya perbedaan dari persentase terkontaminasinya ekplan dise-babkan bahan yang terkandung dalam bayclin telah mampu mengurangi terjadi tingkat terkontaminasi dari ekplan karena pada bayclin terdapat senyawa hipoklorit yang sangat efektif dalam menghambat perkembangan mikroorganisme.
Natrium hipoklorit menjadi disinfektan yang banyak digunakan karena memiliki sifat-sifat yang menguntungkan dan termasuk dalam kategori disinfektan yang ideal. Disinfektan ini adalah larutan yang berbahan dasar klorin $\left(\mathrm{Cl}_{2}\right)$. Cairan klorin merupakan disinfektan tingkat tinggi (high level desinfectants) karena sangat aktif pada semua bakteri, virus, fungi, parasit, dan berbagai spora (Olowe et al. 2012). Kemudian tingkat kontaminasi terendah tedapat pada T0 hal ini disebabkan pada perlakuan ini kita tidak memberikan bahan tambahan berupa ZPT yang mungkin bersama bahan yang diberikan, yang dapat menyebabkan terjadinya kontaminasi pada eksplan tersebut.

\section{Panjang Tunas (cm)}

Hasil penelitian menunjukkan bahwa pengaruh konsentrasi bayclin dan BAP pada Media MS terhadap Panjang Tunas secara interaksi berbeda nyata sebagaimana ditampilkan pada Tabel 2.

Dari Tabel 21 terlihat bahwa Panjang Tunas terpanjang terdapat pada perlakuan $\mathrm{K}_{2} \mathrm{~T}_{2}$ $(5,50 \mathrm{~cm})$ berbeda nyata dengan perlakuan lain sedangkan Panjang Tunas terpendek K3T3 (0,73 $\mathrm{cm}$ ) berbeda nyata K0T1, K0T2, K0T3, K1T1, K1T2, K2T1, K2T2, K2T3, K3T2, dan tidak berbeda nyata dengan perlakuan lainnya, terjadi perbedaan dikarenakan pengaruh konsentrasi bayclin dan BAP pada media MS yang dipakai hal tersebut dapat memacu perpanjangan tunas hingga pada perlakuan tertentu dihasilkan panjang tunas yang lebih dan sebaliknya pada perlakuan tertentu dihasilkan Panjang Tunas yang lebih pendek. Untuk itu pada hasil penelitian ini bahwa konsentrasi bayclin 20\% pada pencucian ke-2 dan konsentrasi BAP 1.0 mg/liter pada Media MS telah mampu

Tabel 1. Rerata Persentase Eksplan Terkontaminasi (\%) terhadap pengaruh konsentrasi bayclin dan BAP pada Media MS

\begin{tabular}{llllll}
\hline & T0 & \multicolumn{1}{c}{ T1 } & \multicolumn{1}{c}{ T2 } & \multicolumn{1}{c}{ T3 } & Rerata \\
\hline K0 & $33.33 \mathrm{~cd}$ & $41.67 \mathrm{bcd}$ & $50.00 \mathrm{abcd}$ & $83.33 \mathrm{a}$ & $52.08 \mathrm{~b}$ \\
$\mathrm{~K} 1$ & $41.67 \mathrm{bcd}$ & $33.33 \mathrm{~cd}$ & $41.67 \mathrm{bcd}$ & $66.67 \mathrm{abc}$ & $45.83 \mathrm{bc}$ \\
$\mathrm{K} 2$ & $25.00 \mathrm{~d}$ & $50.00 \mathrm{abcd}$ & $33.33 \mathrm{~cd}$ & $33.33 \mathrm{~cd}$ & $35.42 \mathrm{c}$ \\
$\mathrm{K} 3$ & $83.33 \mathrm{a}$ & $66.67 \mathrm{abc}$ & $75.00 \mathrm{ab}$ & $83.33 \mathrm{a}$ & $77.08 \mathrm{a}$ \\
\hline Rerata & $45.83 \mathrm{~b}$ & $47.92 \mathrm{~b}$ & $50.00 \mathrm{~b}$ & $66.67 \mathrm{a}$ & \\
\hline BNJ $=$ & KT & 37.84 & $\mathrm{~K} / \mathrm{T}$ & 13.87 & \\
\hline KK $=$ & $23,76 \%$ & & & & \\
\hline
\end{tabular}

Angka-angka yang diikuti oleh huruf yang sama pada tiap baris dan kolam tidak berbeda nyata menurut uji BNJ pada taraf nyata $5 \%$. 
Tabel 2. Rerata Panjang Tunas $(\mathrm{cm})$ terhadap pengaruh konsentrasi bayclin dan BAP pada Media MS

\begin{tabular}{|c|c|c|c|c|c|}
\hline & T0 & T1 & T2 & T3 & Rerata \\
\hline K0 & $1,17 \mathrm{~g}$ & $2,11 \mathrm{ef}$ & $4,00 \mathrm{~b}$ & $2,43 \mathrm{def}$ & $2,43 b$ \\
\hline $\mathrm{K} 1$ & $1,20 \mathrm{~g}$ & $2,18 \mathrm{ef}$ & $3,37 \mathrm{bc}$ & $0,97 \mathrm{~g}$ & $1,93 \mathrm{c}$ \\
\hline $\mathrm{K} 2$ & $1,17 \mathrm{~g}$ & 2,50 cde & $5,50 \mathrm{a}$ & $3,32 \mathrm{bcd}$ & $3,12 \mathrm{a}$ \\
\hline K3 & $1,17 \mathrm{~g}$ & $1,60 \mathrm{fg}$ & $2,67 \mathrm{cde}$ & $0,73 \mathrm{~g}$ & $1,54 \mathrm{~d}$ \\
\hline Rerata & $1,17 \mathrm{c}$ & $2,09 b$ & $3,88 \mathrm{a}$ & $1,86 \mathrm{~b}$ & \\
\hline $\mathrm{BNJ}=$ & KT & 0,89 & $\mathrm{~K} / \mathrm{T}$ & 0,32 & \\
\hline $\mathrm{KK}=$ & $12,99 \%$ & & & & \\
\hline
\end{tabular}

menghasilkan panjang tunas $5,50 \mathrm{~cm}$. Hal ini sesuai apa yang dikemukan oleh Yusnita (2003) bahwa penggunaan sitokinin dapat merangsang perpanjangan tunas adventif yang merupakan perkem-bangan organ yang terjadi pada titik tumbuh. Selanjutnya Sumiasri dan Priadi (2002) mengatakan konsentrasi BAP yang optimal untuk memacu pertumbuhan tanaman bervariasi dan tergantung pada jenis tanaman. Oleh karena itu semakin tinggi kandungan BAP sampai batas tertentu dalam tanaman semakin cepat terbentuk tunas. Menurut Pierrik (1981), pemberian sitokinin yang cukup tinggi antara 0-10 mg/l mampu menginduksi pembentukan tunas, tetapi pembentukan akar menjadi terhambat.

\section{Panjang Akar (cm)}

Hasil penelitian menunjukkan bahwa pengaruh konsentrasi bayclin dan BAP pada Media MS terhadap Panjang Akar secara interaksi berbeda nyata sebagaimana ditampilkan pada Tabel 3.

Dari Tabel 3. terlihat bahwa panjang akar terpanjang terdapat pada perlakuan $\mathrm{K}_{2} \mathrm{~T}_{2}(12,08$ $\mathrm{cm})$ berbeda nyata dengan perlakuan lain sedangkan Panjang Akar terpendek terdapat pada perlakuan K1T3 $(1,43 \mathrm{~cm})$ berbeda nyata dengan yang lainya dan tidak berbeda dengan $\mathrm{K} 2 \mathrm{~T} 1$, K3T2, K0T3, K2T3, K3T3, terjadi perbedaan dikarenakan pengaruh konsen-trasi bayclin dan BAP pada media MS yang dipakai dapat mempengaruhi panjang akar, sehingga dihasilkan panjang akar yang berbeda dan pada kosentras yang tepat dihasilkan panjang akar terpanjang pada perlakuan K2T2 dan sebaliknya pada perlakuan tertentu dihasilkan panjang akar terpendek. Pada penelitian ini bahwa konsentrasi bayclin $20 \%$ pada pencucian ke-2 dan konsentrasi BAP $1.0 \mathrm{mg} / \mathrm{liter}$ pada Media MS telah mampu menghasil-kan panjang akar terpanjang. Hal ini sesuai apa yang dikemukan oleh Yusnita (2003) bahwa penggunaan sitokinin dapat merang-sang umbuhan tanaman yang merupakan perkembangan organ dari tumbuhan itu sendiri. Selanjutnya Sumiasri dan Priadi (2002) mengatakan konsentrasi BAP yang optimal untuk memacu pertumbuhan tanaman bervariasi dan tergantung pada jenis tanaman. Oleh karena itu semakin tinggi kandungan BAP sampai batas tertentu dalam tanaman semakin cepat terbentuk tunas.

Tabel 3. Rerata Panjang Akar (cm) Terhadap pengaruh konsentrasi bayclin dan BAP pada Media MS.

\begin{tabular}{clllll}
\hline & \multicolumn{1}{c}{ T0 } & \multicolumn{1}{c}{ T1 } & \multicolumn{1}{c}{ T2 } & T3 & Rerata \\
\hline K0 & $4,83 \mathrm{~cd}$ & $9,48 \mathrm{~b}$ & $4,33 \mathrm{~cd}$ & $1,83 \mathrm{f}$ & $5,18 \mathrm{a}$ \\
$\mathrm{K} 1$ & $4,67 \mathrm{~cd}$ & $3,50 \mathrm{de}$ & $5,33 \mathrm{c}$ & $1,43 \mathrm{f}$ & $3,73 \mathrm{~b}$ \\
K2 & $5,00 \mathrm{c}$ & $2,00 \mathrm{f}$ & $12,08 \mathrm{a}$ & $1,50 \mathrm{f}$ & $5,14 \mathrm{a}$ \\
K3 & $4,75 \mathrm{~cd}$ & $5,50 \mathrm{c}$ & $2,83 \mathrm{ef}$ & $1,50 \mathrm{f}$ & $3,64 \mathrm{~b}$ \\
\hline Rerata & $4,75 \mathrm{~b}$ & $5,12 \mathrm{~b}$ & $6,14 \mathrm{a}$ & $1,57 \mathrm{c}$ & \\
\hline BNJ $=$ & KT & 1,49 & K/T & 0,54 & \\
\hline KK $=$ & $11,17 \%$ & & & & \\
\hline
\end{tabular}

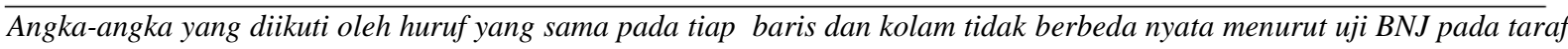
nyata $5 \%$. 
Menurut Pierrik (1981), pemberian sitokinin yang cukup tinggi antara $0-10 \mathrm{mg} / \mathrm{l}$ mampu menginduksi pertumbuhan berupa panjang, tetapi per-panjangan akar menjadi terhambat pada kosentrasi tertentu. Perbandingan konsentrasi antara auksin dengan sitokinin akan mempengaruhi morfologi akar. Apabila perbandingan konsentrasi auksin dengan sitokinin tinggi akan mendorong pemben-tukan akar, sebaliknya apabila perban-dingan auksin dan sitokinin rendah maka akan mendorong pembentukan tunas (Wattimena. 1988).

\section{Persentase Hidup Eksplan}

Hasil penelitian menunjukkan bahwa pengaruh konsentrasi bayclin dan BAP pada Media MS Terhadap Persentase Hidup Eksplan secara interaksi berbeda nyata sebagaimana ditampilkan pada Tabel 4.

Dari Tabel 4 terlihat bahwa Rerata persentase hidup eksplan tertinggi yang terdapat pada perlakuan $\mathrm{K}_{0} \mathrm{~T}_{0} 75 \%$, berbeda nyata dengan perlakuan K3T0, K2T1 K3T1, K0T2, К0T3, К1T2, К3Т2, К0T3, К1T3, K2T3, K3T3 dan tidak berbeda nyata dengan perakuan K0T1, K1T0, K1T1, K2T0, K2T2, sedangkan persentase hidup eksplan terendah yang terdapat pada perlakuan K3T3(0\%), berbeda nyata dengan K0T0, K0T1, K0T2, K1T0, K1T1, K1T2, K1T3, dan tidak berbeda nyata dengan perlakuan K3T0, K3T2, terjadi perbedaan dikarenakan pengaruh konsentrasi bayclin yang digunakan sebagai pecuci dari pada eksplan sehingga dapat merusak jaringan yang ada pada bahan tanaman yang dipakai sebagai eksplan hingga menyebabkan eksplan tidak mampu untuk hidup dan berkembang hal ini terlihat dari hasil kajian ini semakin tinggi bayclin yang diikuti oleb BAP yang tinggi tanaman tidak mau untuk hidup ini pada perlakuan K3T3, hal ini disebabkan adanya Senyawa hipoklorit yang sangat efektif dalam membunuh mikroorga-nisme serta memiliki $\mathrm{pH}$ yang tidak stabil, bersifat toksik sehingga dapat merusak jaringan pada bagian pomotongan eksplan. Penggunaan senyawa kimia bayclin $20 \%$ dan alcohol $70 \%$ mampu mengurangi kontaminasi baik ekster-nal maupun internal yang disebabkan oleh jamur maupun bakteri. Waktu perendaman eksplan dalam senyawa kimia sterilan dengan lama waktu perendaman berkisar 5-10 menit mampu menurunkan kontaminasi antara 35-56 \% dalam penelitian ini. Kombinasi penggu-naan senyawa kimia bayclin 20\% dan alcohol $70 \%$ selama 10 menit mampu menurunkan kontaminasi pada eksplan berkisar $42 \%$ (Shofiyani dan Hajoeningtijas. 2010). Natrium hipoklorit menjadi disinfektan yang banyak digunakan karena memiliki sifat-sifat yang mengun-tungkan dan termasuk dalam kategori disinfektan yang ideal. Disinfektan ini adalah larutan yang berbahan dasar klorin $\left(\mathrm{Cl}_{2}\right)$. Cairan klorin merupakan disinfektan tingkat tinggi (high level desinfectants) karena sangat aktif pada semua bakteri, virus, fungi, parasit, dan berbagai spora. Kemampuan disinfeksi natrium hipoklorit terletak pada kemampuannya membentuk asam hipoklorit ( $\mathrm{HOCl})$. Asam hipoklorit akan terbentuk apabila natrium hipoklorit dilarutkan dengan air. Asam hipoklorit akan melepaskan klorin yang akan menempel pada lipoprotein dinding sel bakteri kemudian membentuk senyawa toksik yaitu $\mathrm{N}$-chloro yang dapat mengganggu pembelahan sel, menghentikan regenerasi sel dan mengakibatkan kematian bakteri (Olowe et al. 2012).

Tabel 4.'Rerata Persentase Hidup Eksplan (\%) terhadap pengaruh konsentrasi bayclin dan BAP pada Media MS

\begin{tabular}{llllll}
\hline & \multicolumn{1}{c}{ T0 } & T1 & \multicolumn{1}{c}{ T2 } & T3 & Rerata \\
\hline K0 & $75.00 \mathrm{a}$ & $50.00 \mathrm{abcd}$ & $41.67 \mathrm{bcde}$ & $25.00 \mathrm{def}$ & $47,92 \mathrm{a}$ \\
$\mathrm{K} 1$ & $50.00 \mathrm{abcd}$ & $66.67 \mathrm{ab}$ & $33.33 \mathrm{cde}$ & $33.33 \mathrm{cde}$ & $45,83 \mathrm{a}$ \\
$\mathrm{K} 2$ & $58.33 \mathrm{abc}$ & $33.33 \mathrm{cde}$ & $58.33 \mathrm{abc}$ & $41.67 \mathrm{bcde}$ & $47,92 \mathrm{a}$ \\
$\mathrm{K} 3$ & $25.00 \mathrm{def}$ & $16.67 \mathrm{ef}$ & $25.00 \mathrm{def}$ & $0.00 \mathrm{f}$ & $16,67 \mathrm{~b}$ \\
\hline Rerata & $52,08 \mathrm{a}$ & $41,67 \mathrm{ab}$ & $39,58 \mathrm{~b}$ & $25,00 \mathrm{c}$ & \\
\hline BNJ & $\mathrm{KT}$ & 32.77 & $\mathrm{~K} / \mathrm{T}$ & 11.97 & \\
\hline $\mathrm{KK}=$ & $27,35 \%$ & & &
\end{tabular}




\section{KESIMPULAN DAN SARAN}

Hasil penelitian ini dapat disimpulkan bahwa pengaruh konsentrasi bayclin pada pencucian ke-II dan konsentrasi BAP pada Media MS terhadap pertumbuhan eksplan tanaman pisang klutuk secara in vitro diperoleh perlakuan terbaik K2T2 (konsentrasi bayclin $20 \%$ pada pencucian ke-II dan konsentrasi BAP $1,0 \mathrm{mg} /$ liter pada Media MS) dengan persentase terkontaminasi 33,33\%, Persentase hidup $58.33 \%$, panjang tunas $5,50 \mathrm{~cm}$, jumlah akar 2,67 buah dan panjang akar/eksplan 12,08 cm. Dari hasil penelitian menyarankan untuk menggunakan konsentrasi bayclin 20\% pada pencucian ke-II dan konsentrasi BAP 1,0 $\mathrm{mg} /$ liter pada Media MS yang merupan hasil terbaik dari penelitian ini.

\section{DAFTAR PUSTAKA}

Abdurrahman. 2011. Cara Budidaya Tanaman Pisang (Musa SPP) Bag. 2) Indonesia: Departemen Kementerian Pertanian Indonesia. Jakarta.

Asnin. 2010. Laporan Hasil Pelaksanaan Kegiatan Laboratorium Kultur Jaringan (UPT Benih ) Dinas Tanaman Pangan Dan Holtikultura Propinsi Riau, Indonesia : Dinas Pertanian Provinsi Riau, Pekanbaru.

Shofiyani, A., dan O. D. Hajoeningtijas. 2010. Pengaruh Sterilan dan Waktu Perendaman Pada Ekplan daun Kencur (Kaemferia galanga L) Untuk Meningkatkan Keberhasilan Kultur Kalus. Jurnal Agritech. 7(1): 11-29.
Olowe O, Adesoye A, Ojoba O, Amusa O, Liamngee S. Peiris SE, de Silva EDUD, Edussuriya M, Attanayake AMURK, Peiris BCN. 2012. CSUP Thechnique: A Low Cost Sterilization Method Using Natrium Hipoklorit To Replace the Use of Expensive Equipment in Micropropagation. Joural Natn Science Foundation Sri Lanka 40(1):49-54.

Pierik, R. L. M. 1987. In Vitro Culture of Higher Plant. Departement of Horticul-ture, England

Riadi, I. 2010. Pengaruh Kinetin dan BAP terhadap Prtumbuhan dan Perkembangan Emrio Somatik Tanaman Sagu (Metroxylon sagu Rottb). Balai Penelitian Bioteknologi Perkebunan Indonesia. Bogor.

Sandra. 2010. Bahan Kuliah Kultur Jaringan. Pustaka Lentera, Jakarta.

Shofiyani, A., dan O.D. Hajoeningtijas. 2010. Pengaruh Sterilan dan Waktu Perendaman Pada Ekplan daun Kencur (Kaemferia galanga L) Untuk Meningkatkan Keberhasilan Kultur Kalus. Jurnal Agritech, 12(1): 11-29.

Wattimena, G.A. 1988. Kultur Jaringan Pada Tanaman Hortikultura (Aspek dan Prospek Hortikultura). Pelatihan Teknik Kultur Jaringan Tanaman Hortikultura RUTC 5-9 Agustus 2002. Pekanbaru.

Yusnita. 2003. Cultur Jaringan. Cara Memperbanyak Tanaman Secara Efisien. Agromedia, Jakarta. 